\title{
Changes in eating and residence customs: case study of the native community of Mayuriaga, Loreto
}

\section{Cambios en las costumbres alimenticias y de residencia: estudio de caso de la comunidad nativa de Mayuriaga, Loreto}

DOI: $10.46932 /$ sfjdv2n4-063

Received in: May 1st, 2021

Accepted in: Jun 30th, 2021

\section{Jose Yvan Vargas Bourguet}

Professor attached to the Professional School of Anthropology (UNTRM). Forensic Anthropologist Expert of the Institute of Legal Medicine and Forensic Sciences of Peru. Specialist in Forensic Physical Anthropology.

Universidad Nacional Toribio Rodríguez de Mendoza de Amazonas (UNTRM)

E-mail: jose.vargas@untrm.edu.pe

\section{Alex Alonso Pinzón Chunga}

Principal professor of the Faculty of Social Sciences (UNTRM). Director of the Research Institute of Archeology and Anthropology "Kuélap" (INAAK). Specialist in mediation of sociocultural conflicts and public policies.

Universidad Nacional Toribio Rodríguez de Mendoza de Amazonas (UNTRM)

E-mail: alex.pinzon@untrm.edu.pe

\section{Raúl Eleazar Arias Sánchez}

Professor and researcher at the Professional School of Economics of the Faculty of Business Sciences (UNH). Specialist in economic anthropology, qualitative and quantitative methods, poverty, rural economy, strategic teaching, and gamification. Universidad Nacional de Huancavelica (UNH)

E-mail: raul.arias@unh.edu.pe

\begin{abstract}
This research work aims to provide a referential framework of assessment in the context of social damage from the anthropological interpretation of the inhabitants of the native community of Mayuriaga, due to the loss of quality of life, five years after the crude oil spill by part of the Petroperú company occurred in the North Peruvian Pipeline in the Morona River area in the Morona district, Daten de Marañón province, Loreto department, Peru; affecting the lifestyle of the surrounding ethnic communities. This extrapatrimonial damage is expressed and evidenced in eating habits; and residence, in the customs of the traditional use of water, recreation, social stability (tranquility), in the economy, in medicine and in the physical spaces of socialization and social incorporation. Likewise, to know these characteristics, the ethnographic method and on-site visits to the locality that were the subject of our research were used. Finally, we indicate that a quantity of relevant information was collected on the perceptions and changes in the lifestyles of the inhabitants, this thanks to the techniques of interview and observation.
\end{abstract}

Keywords: Community, Mayuriaga, culture, ethnography 


\section{RESUMEN}

El presente trabajo investigación pretende brindar un marco referencial de valoración en el contexto del daño social desde la interpretación antropológica de los pobladores de la comunidad nativa de Mayuriaga, por la pérdida de la calidad de vida, a cinco años después del derrame de petróleo crudo por parte de la empresa Petroperú ocurrido en el Oleoducto Norperuano en la zona del río Morona en el distrito de Morona, provincia del Daten de Marañón, departamento Loreto, Perú; afectando el estilo de vida de las comunidades étnicas aledañas. Este daño extrapatrimonial se expresa y evidencia en los hábitos alimenticios; y de residencia, en las costumbres del uso tradicional del agua, la recreación, la estabilidad social (tranquilidad), en la economía, en la medicina y en los espacios físicos de socialización e incorporación social. Asimismo, para conocer estas características, fue empleado el método etnográfico y las visitas in situ a la localidad motivo de nuestra pesquisa. Finalmente, indicamos que, fue recolectada cantidad de información relevante sobre las percepciones y cambios en los estilos de vida de los pobladores, esto gracias a las técnicas de la entrevista y la observación.

Palabras clave: Comunidad, Mayuriaga, cultura, etnografía

\section{INTRODUCTION}

On February 2, 2016, there was a crude oil spill at kilometer $206+035$ of the ORN, being reported on February 4 of the same year, causing severe and irreversible environmental, psychological, economic and socio-cultural damage in 21 indigenous communities ${ }^{1}$ by where the Morona river crosses. This unfortunate situation not only caused damage to the environmental ecosystem, but also hurt the sociocultural scene of the inhabitants surrounding this ecosystem, therefore, we planned to carry out an anthropological analysis to determine the level of impact of this phenomenon on the development of decisions and habits. of the residents under an intercultural approach. Likewise, we indicate that we took the Wampis community as a study sample due to its proximity, in addition to the fact that they were one of the most affected. In this regard, this research work began by resorting to secondary sources of information such as documentation (between resolutions and reports) in the hands of the Peruvian State, who carried out studies in the affected communities, and we triangulated a comparative analysis with the collection of information product of a field work carried out by the authors in the damaged areas, specifically motivated by the cultural setting. In this sense, from a systemic perspective, we decided to address the issue of changes in the eating habits and residence of the Wampis inhabitant, since this action gives rise to others that allow us to explore and deconstruct various imaginations of behaviour and habits. So, we will find in this preliminary approach to the Mayuriaga community is an exhaustive analysis

\footnotetext{
${ }^{1}$ Comunidad Wampis, Comunidad de Nueva Vida, Comunidad de Puerto América, Comunidad de Puerto Libre, Comunidad de Puerto Alegría, Comunidad de Nuevo Milagro, Comunidad de Nuevo Paragua, Comunidad de Luz del Oriente, Comunidad de Nuevo Porvenir, Comunidad de Dos Hermanos, Comunidad de Vista Alegre, Comunidad de Nuevo Unión, Comunidad de Tierra Blanca, Comunidad de Copales Unidos, Comunidad de San José de Paragua, Comunidad de Bancal, Comunidad de Yamacay, Comunidad de Copacabana, Comunidad de Antena Cuatro, Comunidad de Santa Rosa del Marañón, Comunidad de San Francisco y Comunidad de Mayuriaga.
} 
between the "official" version and the one that was "found in the field", this in order to generate help actions and technical support to this locality, considered as the most affected native community in relation to the rest of the communities since it is the closest locality to the point of the spill $(13 \mathrm{~km})$.

\section{MATERIALS AND METHODS}

The present study used the Ethnographic method, which is a qualitative scientific method typical of social anthropologists and consists of the description of the cultural and social characteristics of a locality, group of people or societies, and that allows obtaining an internal and deconstructed vision of culture by contrasting it with various sources of information, in the words of Giddens (2007 p. 27) this methodology is understood as: "el estudio directo de personas y grupos durante un cierto periodo, utilizando la observación participante o las entrevistas para conocer su comportamiento social, registrando una imagen realista y fiel del grupo estudiado; el trabajo de campo resulta ser una herramienta imprescindible".

In the same way, our research took an objective consideration when gathering greater elements of judgment to determine the sociocultural characteristics of the Native Community of Mayuriaga associated with the impact of the crude oil spill that occurred in the North Peruvian Pipeline in the area of and Morona (Loreto), making a visit to the Native Community of Mayuriaga, District of Morona, Province of Datem del Marañón, Department of Loreto, on November 21 and 22, 2018. Within the act, the interview technique was also used, the which represents a tool that guides the approach and consultation of the problem variables to be ordered and guided based on our initial research objective, for this, we follow the recommendations made by Kalinsky (2002) on its applicability and the scientific criteria to obtain reliable results in social studies. On the other hand, it is relevant to point out that, a fundamental part of the impact assessment carried out, took as a starting point the guidelines of the Cumulative Impact Assessment (EIA), which is a method proposed by USAID (2008) that supports that the various successive environmental and social impacts arising from existing developments can be mutually reinforcing, leading to more serious consequences on the environment and people than each of the developments alone.

\subsection{STDY CONTEXT}

The name of Mayuriaga is taken by the inhabitants of this community because it comes from the word "mayu", the name of a plant that was abundant in ancient times in its territory and was used in the same way as barbasco for fishing. However, other wise men from the community pointed out that it was derived from the word "mayusentsa", where the term "entsa" means water. To get to the community of 
Mayuriaga, you start from the district of Yurimaguas to the district of San Lorenzo ${ }^{2}$, then on a speedboat you go to the community of San Martín ${ }^{3}$, to travel in a "peque peque" 4 to the community of Mayuriaga. The Native community of Mayuriaga is located on the right bank of the Mayuriaga river ${ }^{5}$, which is a tributary of the Morona River. This community is located in the compression of the Morona district, Datem del Marañón province, in the Loreto region. In the community there are the populated centers of Mayuriaga, Patria Nueva and Nuevo San Martín.

The Native Community, the reason for our analysis, has a total area of 27,177 ha and 1,250 $\mathrm{m} 2$. it has a great diversity of flora and fauna, as well as a large number of aguajales, unguragui, wasaí, shebon, among others. In addition, timber resources. It also has streams near hunting areas ${ }^{6}$. Its lakes "Ainipe", "Limón" and "Centro Cocha" are unprotected by the large quantities of fish that are extracted by fishermen who come from the districts of Lagunas and Yurimaguas. They also have an underground water source that facilitates access to clean water for human consumption. Similarly, they have wood resources from different varieties of forest species, such as cedar, screw, papelillo, cumala, estoraque, lupuna, and different species of palm trees ${ }^{7}$. As for the political characterization, we know that it was recognized in 1993, through R.D. 034-93-GRL-DRA and that same year it obtained its degree resolution, R.D. 062-93CTAR-DRA. Finally, we indicate that it is registered in the Database of Indigenous Peoples of the Ministry of Culture, according to Ministerial Resolution No. 321-2014-MC and the Ministry of Development and Social Inclusion has assigned it the socioeconomic classification of extreme poor through Resolution Ministerial N ${ }^{\circ} 227-2014-$ MIDIS.

\subsection{CARACTERIZACIÓN ETNOGRÁFICA}

Regarding their denomination, the Native Community of Mayuriaga is identified as part of the Wampis indigenous ${ }^{8}$ people, and they belong to the Jíbaro ethnolinguistic family. The Awajún and Ashuar are also part of this family, which is why there are many similarities in their way of understanding their environment and worldview, similarities that the people of Mayuriaga themselves recognize and respect today.

One of the most important cultural characteristics of the native community of Mayuriaga is the language with which its population learned to speak, thus being the Wampi language the most widely

\footnotetext{
2 Time of 45 minutes by plane, and 6 hours by speedboat

3 Approximately 4 hours.

${ }^{4}$ Approximately 2 hours.

${ }^{5}$ Access to the community can be difficult and costly for the community resident. When it does not rain, the flow of the Mayuriaga River decreases and the boats or children cannot approach the community. In this sense, the community members must be attentive to know who is traveling outside the community, to be able to send orders or travel.

${ }^{6}$ Mayuriaga, Yanayaco, Sabo Loyaco, Tamsiyaco, Ainipeyaku, Kapunsa, Sabalayacu, Sasá, Iyanpis y Penku

${ }^{7}$ Aguaje, ungurahi, pijuayo.

${ }^{8}$ In Peru there are 10,177 people who speak the language.
} 
used means of communication. The Wampi language is highly valued among its inhabitants since it is considered the main language, even though the teachers who teach at the I.E. From the primary level of the community they communicate in Wampi and Spanish, most of the time, they transmit their teachings through their native language.

Regarding its population, according to the Life Plan of the Mayuriaga Native Community, there are 380 people grouped into approximately 60 families. While, from the information collected in the field, one of the interviewees ${ }^{9}$ mentioned that there are approximately 90 community members, a total population (community members, women and children) of 600 people and 90 families. Mayuriaga's family is made up of all the people with whom there is a blood bond. In the case of the community, as we have already mentioned, it has approximately 60 to 90 families. Traditionally, marriage was preferably between cousins descendants of a brother and sister couple. A marriage between cousins is considered incestuous when the parents or grandparents of the couple are male brothers or female sisters. Regarding this, marriage is valued as a social institution, we mention that pairing, historically was an act that occurred only between members of the same community (endogamous), and currently, despite contact with other neighboring towns and foreigners (presence of migrants), still preserve this cultural pattern of constituting endogamous families, that is, they do not form families between a Wampi and a "hispanohablante" ${ }^{10}$, since taking the latter is considered an infraction of the rules of The community, thus, we point out that the various penalties resulting from breaking the "laws" are stipulated in the Internal Regulations of the Mayuriaga Community (2014). Another sociocultural characteristic collected in our field work was that, the descendants of the Jíbaro ethnic group, historically some men, have had more than one wife, being preferred that the union be with the wife's sister who lives in the same house. If the wives are not sisters, the traditional practice is for the man to build two adjacent houses for each to live in with their respective children. Currently this practice is not repeated in the same way, however there are isolated cases as part of the cohabitation relationship of more than one wife, but this practice has a sanction, according to what is stated in its regulations.

On the other hand, the sexual initiation of women from the native community of Mayuriaga occurs between 13 and 15 years $^{11}$, as indicated by their authorities. There is also a differentiation of roles, for example, community fathers teach their sons to hunt and fish and mothers teach their daughters to weave beads or necklaces at home. Both the father and mother teach the Wampis language from an early age. Stories are told where places of spiritual importance to the community are mentioned. However, a

\footnotetext{
${ }^{9}$ Entrevista realizada el 21/11/18 al Sr. Abel Huasanga, Apu de la Comunidad.

${ }^{10}$ It is the term used by the Wampis to refer to a person who is not part of their community (for example, a mestizo)

${ }^{11}$ In this regard, Iriarte (2003; p. 223) points out: “... en sociedades como éstas (menos complejas), es posible que la iniciación se produzca en la pubertad o antes de entrar en ella, pero tal iniciación puede postergarse por uno u otro motivo, razón por la cual no todos alcanzan la edad adulta, socialmente hablando, a la misma edad cronológica".
} 
circumstance that the authorities of the Mayuriaga Community regret is that, due to the oil spill generated by the Petroperú company, there has been a negative impact on the learning process within the home, where now parents do not spend much time with their sons and daughters, since they are absent for long periods (weeks or a month) to work in the camps of the company in question. Regarding its basic services and state assistance, the Mayuriaga community has a primary level educational institution No. 62168 with modular code 0548644 and an initial level educational institution with modular code 1548171 . There is no secondary education. However, for the residents of Mayuriaga, having a secondary education is very important. For this reason, at the end of primary education, their sons and daughters must go to study in other places; Some travel to Puerto América or Puerto Alegría (Morona district), where there are public educational institutions, while others prefer to apply to the bilingual boarding school "Yankuam Jintia" in San Lorenzo, in the district of Barranca, where all educational expenses are paid. To date, a school is being built by the State. It is important to indicate that the teachers at the primary level belong to the Wampis people, although they come from other communities. Their employment status is that of hired, for that reason most teachers are sent to different schools each year. Only three of the eight teachers are from the Mayuriaga community.

With regard to health services, the Mayuriaga community has a Health Post, with the presence of a Health Technician who attends permanently, this professional belongs to the Shawi indigenous people. Similarly, this establishment has the support of two volunteer health promoters, who are community members of Mayuriaga. Every time the technician is absent for a health brigade, the promoters undertake emergency training. However, not everything is favourable, the leaders of the Mayuriaga community maintain that the canned foods distributed by the Petroperú company to the community members who settle in the camps to work, are causing skin problems, also due to the work clothes that make them wear, urinary infections are increasing. Faced with these health problems, the villagers turn to their ancestral knowledge about plants, fruits and animals to heal themselves ${ }^{12}$.

On the other hand, Mayuriaga does not have electricity and drinking water services. They get their water from the Mayuriaga River, although after the oil spill they choose to use the water ${ }^{13}$ that comes from the springs which are located long distances and many hours on the road. To supply themselves with electricity, they use a light generator in the community. Few people have a generator. Also, the town has two satellite phones and a radio.

\footnotetext{
12 Traditional medicine in the population of Mayuriaga has a strong resistance to conventional medicine, according to the ethnographic study, yerba luisa is still used to clean the stomach when the stomach is "bulging", likewise. The guava leaf is very useful to stop diarrhea. Ginger is used to relieve stomach pain. Likewise, the use of animals for the cure and treatment of diseases is common within the Community of Mayuriaga, for example, the fat of the fox and the iguana is used to cure fever and bronchitis.

${ }^{13}$ According to the leaders, the Petroperú company no longer distributes water, where by Supreme Decree No. 081-2007-EM they are obliged to deliver drinking water and food to all affected communities.
} 
The presence of the State in this community is manifested through the benefits that its inhabitants perceive through the Itinerant Platform of Social Action (PIAS) that is characterized by a river transport operated in an itinerant way by the Peruvian Navy, who navigate the Morona River and reach the Nuevo San Martín community, offering the benefits of Social Programs ${ }^{14}$. These programs reach the Nuevo San Martín community, being this place where the residents of Mayuriaga move to receive services and benefits. While Qali Warma, it is a program that periodically distributes food in the I.E. of initial and primary of the community. The mothers of families are in charge of preparing the food in their homes. The foods provided by the aforementioned program are rice, noodles, canned food (tuna), cookies, sugar, milk and oatmeal. However, canned products are consumed with great fear due to the illnesses they have caused in the community members who worked in the camps ${ }^{15}$. Finally, we point out that, regarding the visit by the State after the impact of the crude oil spill, there have only been three.

\section{RESULTS}

Within the cultural sphere, we have established seven activities by which the culture of the native community of Mayuriaga is governed and which have been violently modified from the impact of the crude oil spill in the Morona River. On occasion, we will only talk about food and residence customs since, in our opinion, it is the most important.

\subsection{FOOD AND RESIDENCE CUSTOMS}

Before the oil spill, the diet of the Mayuriaga community was based on agricultural products for selfconsumption such as hard yellow corn, soft corn, sachapapa, sweet potato, plantain, cassava, rice and beans, of which the first two are grown on the river bank. These foods were accompanied with the fish they obtained from the river, nearby cochas and distant lakes such as boquichico, catfish, lisa, palometa, tucunaré, fasaco, tarpon, bujurki, paña, shuyo, carachama and corvina, thus, the food that completed their diet was the meat of bush animals obtained as part of their hunting activities, some of them are the majaz, sacha vaca sajino huangana añuje carachupa birds pucacunga deer chozna. Within economic activities in general, currently the Wampis depend on their integrity of agriculture, hunting, fishing and minor poultry farming.

The main crops of their farms are bananas, peanuts, corn, yucca, sweet potato or inchi, sachapapa, cane,

\footnotetext{
${ }^{14}$ Programa JUNTOS, Pensión 65, afiliación al Seguro Integral de Salud, RENIEC y del Banco de la Nación.

${ }^{15}$ According to the information collected, there is difficulty in mobilizing the elderly to the community of Nuevo San Martín to receive an economic subsidy or economic bonus from the Pension 65 Program. On the other hand, some mothers do not receive the bonus from the Together program because they cannot afford mobility to Nuevo San Martín since they spend three gallons of fuel, which represents about 45.00 soles. In addition, not all older adults are affiliated with the Pensión 65 program, and this is due to the absence of ID, among other factors..
} 
pineapple and cocoa. The work of the land is highly valued by the inhabitants of Mayuriaga, having an ancestral work system, agriculture being a main activity in the local economy, it is practiced daily, all families have at least two farms and some can To have more. Sowing occurs for a period, and then the land is allowed to rest, beginning to work on the other field. For example, after six months it is already being harvested, in a year everything is finished. According to the interviewees, a farm can last between 3 to 4 years, after this period "se tiene que hacer otra chacra" y quien no hace chacra tienen que sufrir de hambre por eso nosotros salimos diario a la chacra" ${ }^{\prime 17}$

In this regard, Ochoa (1990) argues that, “...así como la mayoría de las etnias amazónicas practican la agricultura de rozo y quema, lo cual consiste en despejar las parcelas, sembrarlas y una vez realizada la cosecha, dejar reposar a la tierra. Este sistema permite al suelo de nutrirse de nuevo." (p. 30)

While Regan (2007 p.15) mentions that “...la mujer cumple un rol principal. Es ella la encargada de mantener la chacra y cosechar la yuca. Es decir, la comunidad de Mayuriaga tienen una ideología que asocia la división del trabajo con la oposición hombres/mujeres."

The products of the land are obtained for self-consumption, and what can be commercialized, is taken to the district of San Lorenzo, although this, in the perception of the community members, is not very profitable due to the expense and time that the trip is generated. to the designated place. Fishing is another important activity for this community, and according to the inhabitants, its territory has main lakes where it is fished in an artisanal way, using nets and hooks. The species that are most found in these lakes are: boquichico, tucunare, fasaco, catfish, añashuya, bujurqui, tarpon, shuyo, black cunchi, among others. In the streams, fishing is also done by hand, but using barbasco (Timu) and huaca (masu). From the huaca the leaf is used; and of the barbasco, the root: it is crushed with ash and chili pepper, to make it stronger and thrown into the water so that the fish die. These products are also part of the diet of the inhabitants. As in agriculture, parents teach their children from seven and eight years to fish, repeating this procedure generation after generation.

Hunting activities are inherent to this locality, in the places where they were carried out in remote times, even the first Wampis inhabitants came to the current territories looking for bush animals for consumption. The ancient settlers used the pukuna (uиm), an instrument made of two-meter-long pona, and they also poisoned the pukuna's darts with ampi (tseas), a powerful poison that is extracted from a rope (vegetable liana).

On the other hand, men are associated with hunting and relationships with what is "external" to the social universe itself: hunting is the quintessential male activity and implies moving away, in a greater

\footnotetext{
${ }^{16}$ The men are in charge of opening the farm; cut down all the big trees on the land, then the woman comes in to cultivate.

${ }^{17}$ Entrevista realizada el 21/11/2018 a un poblador comunidad nativa de Mayuriaga.
} 
radius, from the domestic space limited to hunting and hunting. the farm (Fuentes, 1988 p. 135).

From an early age, men are instructed in the art of hunting, at the age of $\operatorname{ten}^{18}$, they are already taken to the mountain by their parents to learn to hunt animals, this training lasts between one to three days approximately. At present, in addition to these tools, firearms such as shotguns and retrochargers are used, which have been socially inherited in most cases, and in others they have been acquired by buying them in a neighboring town. Thus, there is an association and combination between the use of firearms ${ }^{19}$ and the traditional hunting of animals. The most recurrent animals hunted are: the picuro (majaz), sachavaca and achuni (armadillo-shushui), the tapir and the sajino. Within this context of bush animal hunting, one of the concerns collected by the informants is regarding the doubt they have that if the animals they hunt for food are also contaminated due to the oil spill that occurred as One of the interviewees mentioned: “...los animales como el picuro (majaz), sachavaca y achuni (armadilloshushui) no piensan como humano, se bañan dónde está el petróleo y cruzan la quebrada y se mueren". 20

Likewise, the food diet is complemented with the collection of species suri (mukin) and curuhuinse (week) and various fruits (star apple, shimbillo, pijuayo, among others). The raising of birds and small animals is important in the subsistence of families. The women of the community are the ones who are aware of the raising of birds, most of the mothers of Mayuriaga raise hens, chickens, ducks and turkeys. Finally, another activity that not all men carry out, is within the context of the oil spill where the community members perform labor services for Petroperú's contractor companies, which are in charge of clearing, excavating land or organic waste. For this work, they told us that they received a daily payment of S /. 150.00 (150/00 ciento cincuenta soles), which allowed them to increase the budget for the family basket. This possibility of higher income has motivated some families to open stores in the community to benefit as well. However, not all families have increased their income and the situation is complicated since, after the spill, the prices of basic necessities had a significant increase. At present, this daily payment for the work in question has decreased, with the amount received being S /. 80.00 (80/00 ochenta soles) daily.

Until 2016, land, water and bush meat products were part of the diet of this community. As of that year, due to the oil spill that occurred, this social dynamic underwent significant changes, such as agricultural products dried up (soft corn, yucca), the sachapapa plants were affected by fungi, as well as, appeared stink bug on bean leaves. In 2017, these difficulties continued. In 2018, worms and potatoes

\footnotetext{
${ }^{18}$ In this regard, Csordas (1999, p. 181) postulates that: "tanto la cultura como el ser pueden ser entendidos en términos de la incorporación como una condición existencial en la cual el cuerpo es la base subjetiva e intersubjetiva de la experiencia"

${ }^{19}$ Another research carried out in the Peruvian Jungle, indicates that, of the 460 family groups surveyed, a total of 18316 gauge shotguns, American or Spanish manufacture, owned in total. Only some of the groups possessed more than one weapon. While other family groups stated that they rent weapons from their neighbors for their hunting operations. (Paul. Pierret and Marc J. Dourojeanni, 1996).

${ }^{20}$ Entrevista realizada el 22/11/2018 a un dirigente de la comunidad nativa de Mayuriaga.
} 
sprouted on the banana, and the leaves of the yucca plant turned yellow. In 2019, the hard-yellow corn had worms, in addition the grain did not set, and the existence of rats were calamities that added to this ecological disaster. Other fruits, such as the banana, continued to present worms and potatoes. Unfortunately, what was referred to in previous lines continued throughout 2020. As for fish, the community did not fish due to the remediation work by the Petroperú company. In 2017, they had to change a new mesh by not catching the large fish, for a smaller mesh to obtain small fish. The changes for the years 2018, 2019 and 2020 remained the same. Regarding the consumption of bush meat, the inhabitants had to make a change in this type of diet, since the animals had moved to more remote and cleaner mountainous areas, and in other things, they were found dead.

Regarding the use of firearms associated with hunting and self-defense ${ }^{21}$, there are investigations carried out in the Peruvian jungle, in which it is indicated that, of the 460 family groups surveyed, a total of 183 16-gauge shotguns, American-made or Spanish. Only some of the groups possessed more than one weapon, while other groups reported renting weapons from their neighbors for their hunting operations (Paul V. Pierret and Marc J. Dourojeanni, 1996). Another factor that has allowed the change in food dynamics is the introduction of new foods in the community. We refer to the canned food distributed by the Petroperú company to the community members who settled in the camps to work, it is alarming that the residents refer that their consumption has caused skin problems, this during the period of 2016. All these circumstances, have generated cultural changes in its inhabitants, since they are prevented from obtaining agricultural products through agriculture, river fish through fishing, and bushmeat through hunting.

\subsection{Comparative anthropological analysis of the study setting}

In this section we will carry out an anthropological interpretive analysis taking as a basis for comparison the existing documentation on the damage caused by the crude oil spill in the Morona River signed by the different intervening state agencies, and our field work carried out.

Table 1.- Comparative analysis between documentation and field work on cultural damage to eating and residence customs

\begin{tabular}{|c|}
\hline 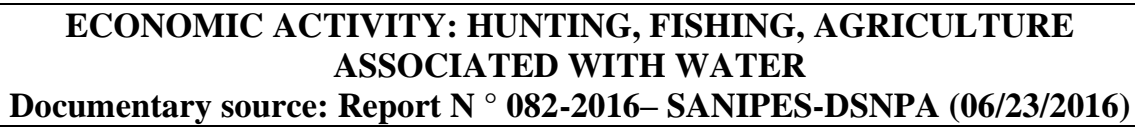 \\
\hline ANTHROPOLOGICAL ANALYSIS \\
\hline
\end{tabular}

\footnotetext{
${ }^{21}$ Correa (1943) in Fuentes (1988), describes one of the last "massacres" of the Aguarunas that occurred in January 1925, in which the Aguarunas attacked the houses of the Chayahuitas with firearms and set fire to said houses, killing 15 people and imprisoned 19 children and women. For their part, the Chayahuitas, after this massacre, immediately organized a punitive expedition and pursued the Aguarunas to the place where the Aguarunas were celebrating their victory. There they attacked and killed five, but in the absence of ammunition, they could not exterminate them, or rescue their captured wives and children.
} 
Conclusion: The species manitoa, catfish, sardine, piranha and mota ruro, boquichico and punctate motorcycle present cadmium outside the permissible limits, likewise the samples of boquichico, cahuara present lead exceeding the maximum permissible limits, and the samples of piranha present mercury that They exceed the maximum permissible limits, as these heavy metals are bioaccumulative, they could be considered a danger to the health of the population.

Recommendation: Maintain the restriction of extraction and consumption of water resources in these areas, as there is the presence of heavy metals in various samples (cadmium, mercury and lead).
Impact on eating habits: The food diet is complemented, in addition to agricultural products, fishing, hunting and the raising of minor birds, the collection of species suri (mukin) and curuhuinse (week) and various fruits (caimito, shimbillo, pijuayo, among others). The raising of birds and small animals is important in the subsistence of the families of the communities through which the Morona River flows. Historically, the women of the Mayuriaga Community are the ones who are aware of the breeding of birds, most of the mothers raise hens, chickens, ducks and turkeys. However, these customs have undergone enormous changes due to the fact that all these consumption animals are contaminated. These cultural changes arise from the problems faced by the population regarding their dietary regimen, being damaged their sources of food resources. The aversion to risk is evident in the inhabitants of the affected communities since they are forced to choose which new foods they should consume.

Impact on residence customs: The residents see the river as their market, which has always been available to supply their diet, but now they have to move away from their places of residence to seek cleaner waters that can offer uncontaminated fish. The contamination of fish by the oil spill has not only generated cultural changes in new diets, but also changes in hunting and fishing habits in new spaces, breaking the social cultural heritage on it.

Source: Own elaboration, 2021

\section{DISCUSIÓN}

In principle, we will mention that the social spaces where the population of Mayuriaga has been formed, have been damaged in irreparable magnitudes, since they are spaces where they have been socially incorporated, developing experiences and subjectivities and that allow their culture to be understood from these terms of incorporation ${ }^{22}$. According to the ethnographic framework and cultural analysis, the territory for the community of is considered a very important space, however, the gradual loss of biological diversity; pollution and climate change, among others, make the Wampis villager reflect from a social level, specifically on the living conditions of their own community and family about their health, education, public services (water, sewage, solid waste management), social programs and

\footnotetext{
${ }^{22}$ In this regard, Csordas (1999, p. 181) points out that: "tanto la cultura como el ser pueden ser entendidos en términos de la incorporación como "una condición existencial en la cual el cuerpo es la base subjetiva e intersubjetiva de la experiencia".
} 
everything that has to do with well-being. This exercise arose as a result of a business activity which continues to generate conflicts and contamination, to which is added the fact that the Mayuriaga community has problems with the neighboring towns of Awajun and Shawi. In addition, they are concerned that people who live in other localities enter their territory and take their resources without asking for permission ${ }^{23}$.

The Wampis people have a philosophy of life about retribution and the community good, however, due to what happened, they consider the actions committed by the Petroperú company a serious crime. On the other hand, it is necessary to mention that; It is also true that when it comes to the indigenous world (native), the communal sphere must be prioritized before the personal, since whoever offends a member offends the community, who destroys nature, destroys the territory; Whoever destroys life, destroys the body (sense of reciprocity) and it must have an example to prevent those events from happening again. In this sense, as part of their behavior to protect their nature and the demand to assume responsibilities, the inhabitants of the Mayuriaga community made these decisions already described, even more so when they were within their own space than they they consider as "theirs", where the highest authority is that which they themselves have designated, and whose law is the one they have established themselves, based on their idiosyncrasies.

However, based on the conflict contexts that they have been assuming, and especially in the face of the crude oil spill that occurred in February 2018, that is, a month before the events that were the subject of the tax investigation, and in light of the perception by of the residents of Mayuriaga, that Petroperú was not complying with the agreements established for the benefit of the community, was that the community decided to convene a meeting with the representative of the company in question to resolve the noncompliance problems. Despite the promises and "official dialogues", what has really been happening is that there are forced changes in the lifestyles of the town.

From anthropology, we can understand that this phenomenon must qualify a defense, conservation and protection of the territoriality of the Mayuriaga population since, it is part of their "justice" in a special way, in that sense, for those investigated, this pattern is as a whole, it is based on ancestrally established norms, and that despite the fact that the way of applying them has undergone changes, their essence, they still resist change. These nuances are often not well understood by the "West" and in the face of environmental disasters like these, good agreements cannot be reached, but on the contrary, they generate disorder and chaos, increasingly distancing social actors from a possible solution., a leader told us about her discomfort: “...Petroperú, están enviando frecuentemente lo que se conoce como personal de avanzada, que son su propia gente contratados como relacionistas comunitarios, pero lo que hacen es

\footnotetext{
${ }^{23}$ For example, they fish in their lakes with nets, often for commercial purposes, and they leave nothing to their community.
} 
llegar a la comunidad y otras comunidades para observar lo que hacemos, para saber nuestra situación, para saber de qué queremos tratar y ellos mantener informados a sus jefes, por eso siempre llegan antes que sus jefes". 24

\section{CONCLUSIONS}

From the anthropological context, we determine the existence of serious damages of extrapatrimonial context on food and residence customs, in the customs of the traditional use of water, social stability (tranquility), traditional economy, in traditional medicine and in the spaces of socialization and incorporation social, as a result of the oil spill, which can be evidenced by the ethnographic work carried out. These changes have generated irreparable cultural damage, since these detriments have also stopped cultural processes in people as individual and sociable beings, hindering the development of (spiritual) experiences and subjectivities, as well as the right to use and dispose of their lands, seriously affecting their current and future identity. Being necessary to increase, recover and strengthen the social customs of organization and economic structure and in geographical spaces, recovering what has been learned, the basic knowledge of their customs and social principles.

${ }^{24}$ Entrevista realizada el 21/11/2018 a una dirigente de la Comunidad de Mayuriaga. 


\section{REFERENCES}

Csordas, J. (1999). The Sacred Self: A Cultural Phenomenology of Charismatic Healing. Berkeley: University of California Press.

Fuentes, A. (1988). Porque las Piedras No Mueren. Historia, Sociedad y Ritos de los Chayahuitas del Alto Amazonas. Centro Amazónico de Antropología y Aplicación: Perú.

Giddens, A. (2007). Sociología. Madrid, España: Alianza Editorial.

Iriarte, F. (2003). Antropología. Universidad Inca Garcilaso de la Vega: Lima - Perú.

Kalinsky, B. (2002). Antropología Jurídica. Argentina.

Ochoa, N. (1990). Los Kampopiyapi. Centro Amazónico de Antropología y Aplicación: Perú.

Regan, J. (2003). Valoración Cultural de los Pueblos Awajún y Wampis. Conservación Internacional Perú-Proyecto PD 3/00 Rev.2 F-ITTO. Paz y Conservación Binacional en la Cordillera del Cóndor, Ecuador-Perú. Componente peruano. CAAP: Perú.

United States Agency for International Development (USAID). (2008). Technical Review Guidelines: Energy Generation and Transmission. Vol 1, pt 2. P. 29-52. Recuperado de: https://www.epa.gov/sites/production/files/2014-04/documents/energyvol1.pdf.

Pierret V.P., Dourojeanni, M.J. (1996). Importancia de la caza para la alimentación humana en el curso inferior del Río Ucayali, Perú. Revista Forestal del Perú. Facultad de Ciencias Forestales de la Universidad Nacional Agraria La Molina. 